\title{
TAXONOMIC NOTES ON SOME POLYGLYPTINI: DESCRIPTIONS OF NEW GENUS AND NEW SPECIES (HOMOPTERA, MEMBRACIDAE, SMILIINAE) ${ }^{1}$
}

\begin{abstract}
Taxonomic notes on some Polyglyptini; descriptions of new genus and new species (Homoptera, Membracidae, Smiliinae). The genera Hemiptycha Germar, Metheisa Fowler, Maturnaria Metcalf, Aphetea Fowler, Dioclophara Kirkaldy, and Phormophora Stål, are redescribed; Creonus, gen.n. (type species: Maturna lloydi Funkhouser, 1914), and Aphetea robustula, sp.n. (from Bolivia), are described. Some nomenclatural changes are introduced, as follow: - Hemiptycha Germar, $1833=$ Polyrhyssa Stål, 1869, syn.n.; - Hemiptycha cultrata (Coquebert, 1801), comb.n., = Polyglyptodes flavocostatus Haviland, 1925, syn.n., = Polyrhyssa cultrata maculata Fonseca, 1942, syn.n. - Hemiptycha obtecta (Fabricius, 1803) = Hille herbicola Haviland, 1925, syn.n. - Maturnaria ephippigera (Fairmaire, 1846) = Publilia tumulata Buckton, 1903, syn.n., = Metheisa fowleri Funkhouser, 1927, syn.n. - Creonus lloydi (Funkhouser, 1914), comb.n. - Aphetea parvula (Fabricius, 1803), comb.n., = Aphetea affinis Haviland, 1925, syn.n. - Dioclophara Kirkaldy, $1904=$ Incolea Goding, 1926, syn.n. - Dioclophara viridula (Fairmaire, 1846) = Maturna multilineata Fonseca, 1942, syn.n. - Dioclophara variegata (Goding, 1926), comb.n. = Incolea viridis Goding, 1926, syn.n. - Phormophora maura (Fabricius, 1803) = Darnis dorsata Fabricius, 1803, syn.n.

KEY WORDS. Homoptera, Membracidae, Smiliinae, Polyglyptini, taxonomy
\end{abstract}

Albino M. Sakakibara ${ }^{2}$

The tribe Polyglyptini, as Deitz (1975) states, "is not as well defined as some of other smiliine tribes". Most of the genera, in this tribe, has the pronotum well developed, extended to apex of tegmina, covering more than half of them, and with sides not always longitudinally carinated, occurring in the same genus, species with or without carinae. The venations of both, tegmina and wings, are variable. In the tegmina, almost always, the veins $\mathbf{R}, \mathbf{M}$, and $\mathbf{C u}$ are separated near the base; but in some cases the $\mathbf{R}$ and $\mathbf{M}$ are distinctly united near the base or along the basal half. The discoidal cell $\left(\mathbf{R}_{\mathbf{2}+3}\right)$ may be present or not. The wings show two patterns of venation: with four apical cells, the second one distinctly peciolated, or with three apical cells where $\mathbf{R}_{4+5}$ and $\mathbf{M}_{\mathbf{1}+\mathbf{2}}$ are not separated.

The genera here treated can be distinguished by the following key:

1) Contribuição número 921 do Departamento de Zoologia, Universidade Federal do Paraná.

2) Departamento de Zoologia, Universidade Federal do Paraná. Caixa Postal 19020, 81531-990 Curitiba, Paraná, Brasil. Bolsista do CNPq. 
1. Wings with four apical cells; the second one distinctly peciolated. $\mathrm{R}_{4+5}, \mathrm{M}_{1+2} \ldots$

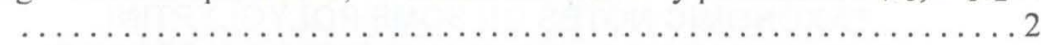

- Wings with three apical cells; $\mathrm{R}_{4+5}+\mathrm{M}_{1+2} \ldots \ldots \ldots \ldots \ldots \ldots \ldots \ldots \ldots \ldots \ldots \ldots \ldots \ldots \ldots$

2. Tegmina with $\mathrm{R}$ and $\mathrm{M}$ distinctly separated near base $\ldots \ldots \ldots \ldots \ldots . \ldots$

- Tegmina with $\mathrm{R}$ and $\mathrm{M}$ united near base ............... Hemiptycha

3. Tegmina with five apical cells. ..................... 4

- Tegmina with (apparently) four apical cells .................. Metheisa

4. Fifth apical cell of tegmina smaller than the fourth ............Maturnaria

- Fifth apical cell of tegmina larger than the fourth ......... Creonus, gen. $\mathbf{n}$.

5. Tegmina with $\mathrm{R}$ and $\mathrm{M}$ separating near base ............... Aphetea

- Tegmina with $\mathrm{R}$ and $\mathrm{M}$ united up to middle $\ldots \ldots \ldots \ldots \ldots \ldots \ldots \ldots$

6. Tegmina with basal cell $\mathrm{R}$ very small $\ldots \ldots \ldots \ldots \ldots \ldots \ldots$ Dioclophara

- Tegmina with basal cell R normal ................. Phormophora

\section{Hemiptycha Germar, 1833}

Hemiptycha Germar, 1833: 177 (type species: Membracis obtecta Fabricius, 1803, by subseq. desig.); Metcalf \& Wade, 1965: 672; Deitz, 1975: 103.

Polyrhyssa Stål, 1869: 26 (Type species: Membracis cultrata Coquebert, 1801), by monotypy); Metcalf \& Wade, 1965: 1019; Deitz, 1975: 103. Syn.n.

Germar's description. "III. Elytrorum margo internis sub stethidio reconditus.

I. Elytra dichotome venosa, cellulis subaequalibus.

a) Vertex trigonus."

Diagnosis. Pronotum tectiform, with lateral carinae more or less evident; median carina percurrent and foliaceous; anterior process obtuse and without lateral carinae. Tegmina with $\mathbf{R}$ and $\mathbf{M}$ united near base for a short distance; wings with four apical cells.

Description. Head triangular, roughly punctured, about twice wider than long; superior margin deeply sinuate; supra-antennal ledges with margins sinuous, in a continuous line with that of clypeus; this diamond-shaped, in the same plan of vertex, apex slightly globose and densely pilose. Eyes ovate. Ocelli situated on an imaginary line that passes through center of eyes, a slightly nearer to eyes and superior margin than to each other. Pronotum roughly punctured, tectiform, covering about half of tegmina, terminating together with the apex of them; dorsal line widely arched, median carina percurrent and foliaceous; lateral longitudinal carinae behind humeral angles well developed or reduced to irregular longitudinal elevated smooth lines near lateral margins; anterior process projected obliquely in front of head, blunt, somewhat conical and without lateral carinae. Tegmina with the exposed basal half coriaceous, roughly punctured as pronotum; veins $\mathbf{R}, \mathbf{M}$, and $\mathbf{C u}$ more or less parallel to just beyond middle; $\mathbf{R}$ and $\mathbf{M}$ united near base along a short distance; five apical cells, the third smaller (sometimes absent); the fifth the largest 
with its area superior than those of precedent four cells together; discoidal cell $\mathbf{M}$ not always present. Wings with four apical cells, the second one peciolated.

Comments. The members of this genus present the pronotum tectiform, widely arched, projected anteriorly in a blunt process which is somewhat conical and inflated, devoid of lateral carinae. The veins $\mathrm{R}$ and $\mathrm{M}$ are united at the base for a short distance.

Polyrhyssa Stål is here considered a junior synonym of Hemiptycha Germar because it differs only by having the lateral carinae of pronotum well developed. In Hemiptycha these carinae are reduced to 4-5 weak elevated lines near the lateral margins.

\section{Hemiptycha cultrata (Coquebert, 1801), comb.n.}

Fig. 2

Membracis cultrata Coquebert, 1801: 77 (type loc.: America Meridionali)

Polyglyptodes flavocostatus Haviland, 1925: 255 (type loc.: Guiana, Kartabo); Metcalf \& Wade, 1965: 1000 (= Polyglyptodes cornigera Stål), syn.n.

Polyrhyssa cultrata maculata Fonseca, 1942: 134 (Type loc.: Brazil, Pará, Belém); Metcalf \& Wade, 1965: 1020, syn.n.

Polyrhyssa cultrata; Metcalf \& Wade, 1965: 1019

Hemiptycha obtecta (Fabricius, 1803)

Fig. 1

Membracis obtecta Fabricius, 1803: 13 (Type loc.: America Meridionali)

Hille herbicola Haviland, 1925: 255 (Type loc.:Guiana, Kartabo); Metcalf \& Wade, 1965: 1014 (= Hille altifrons Walker); Broomfield, 1971: 353 (lectotype desig.), syn.n.

Hemiptycha obtecta; Metcalf \& Wade, 1965: 676; Deitz, 1975: 102 (lectotype desig.).

\section{Metheisa Fowler, 1896}

Metheis $a$ Fowler, 1896: 132 (type species: Metheisa lucillodes Fowler, 1896, by monotypy); Metcalf \& Wade, 1965: 1020; Deitz, 1975: 103

Diagnosis. Pronotum navicular, low, with 3-4 lateral longitudinal carinae, projected anteriorly in a short and blunt process, laterally carinated. Tegmina with apparently four apical cells.

Description. Head triangular, apex deflected, roughly punctured, about as wide as long; superior margin arched, slightly emarginated at middle; supra-antennal ledges with margins sinuate, in a continuous line with that of clypeus; this diamond-shaped, with apex rounded and deflected. Eyes ovate and prominent. Ocelli conspicuous, slightly nearer to the eyes and superior margin than to each other. Pronotum navicular, very slightly constricted after humeral angles, roughly punctured, covering about half of the tegmina, extended posteriorly to the tips of them; with 3-4 lateral longitudinal carinae extended from metopidium to posterior apex, well marked after humeral angles; anterior process short, projected obliquely, obtuse, with 3-4 carinae that join with those lateral longitudinal; median carina 


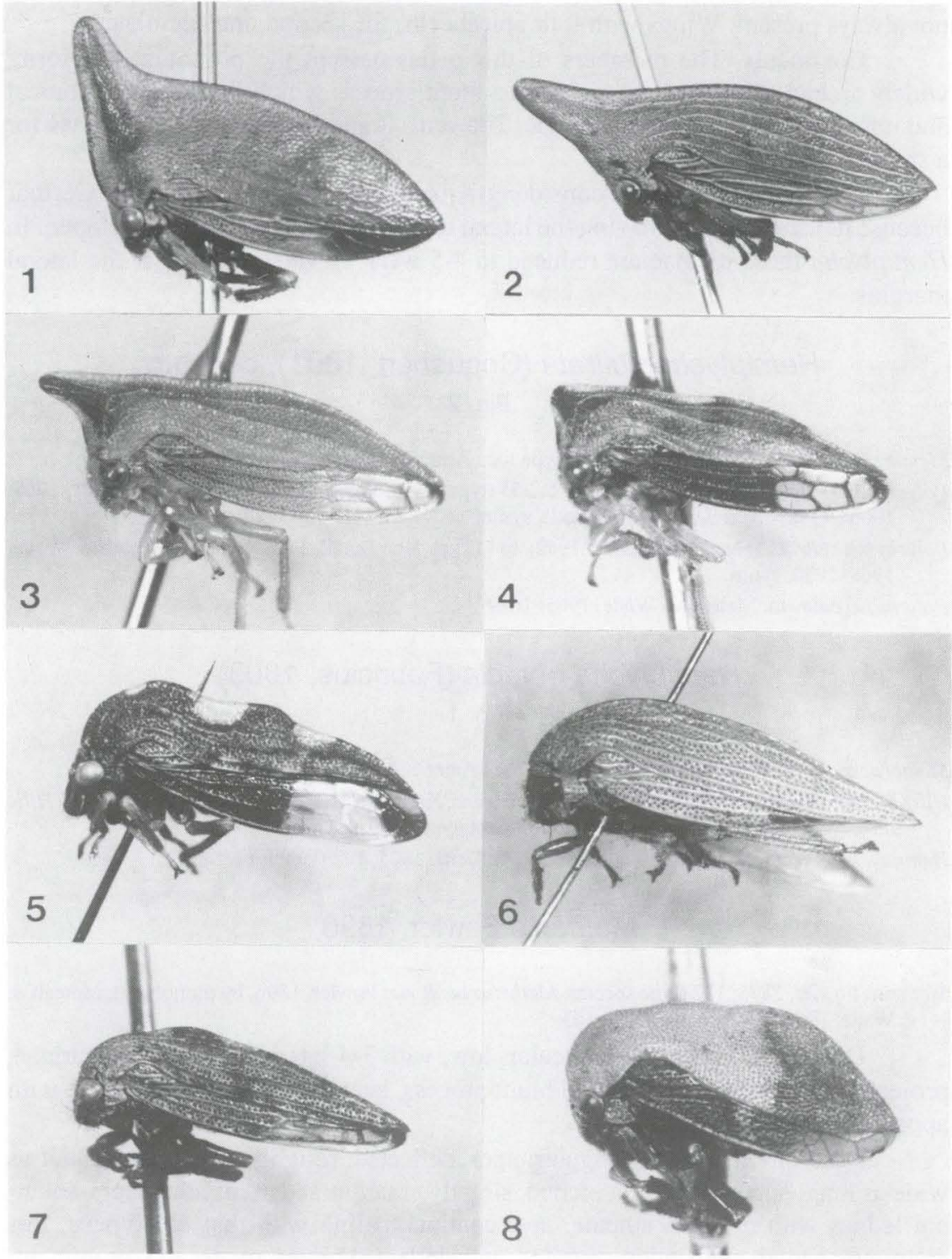

Figs 1-8. (1) Hemiptycha obtecta (Fabricius, 1803); (2) Hemiptycha cultrata (Coquebert, 1801); (3) Metheisa lucillodes Fowler, 1896, female; (4) Metheisa lucillodes, male; (5) Maturnaria ephippigera (Fairmaire, 1846); (6) Creonus lloydi (Funkhouser, 1914), female; (7) Creonus Iloydi, male; (8) Aphetea robustula, sp.n., holotype. 
percurrent and distinctly foliaceous; dorsal contour line almost straight from apex of anterior process to middle where it deflexes slightly and then widely arched toward apex; humeral angles obtuse, not projected; post-ocular lobule normal, triangular, the distance eye-mesepisternal hook almost equal the length of the hook. Tegmina with exposed basal half coriaceous, with same punctures as of pronotum; veins $\mathbf{R}, \mathbf{M}$, and $\mathbf{C u}$ separated from base to middle, joining only at the junction with claval suture; with five apical cells but, the fourth with vein $\mathbf{M}_{\mathbf{3}+\mathbf{4}}$ joining $\mathbf{M}_{\mathbf{1}+\mathbf{2}}$ before reaching marginal vein; one discoidal cell $\left(\mathbf{R}_{\mathbf{2}}+\mathbf{3}\right)$. Wings with four apical cells, the second peciolated.

Comments. This genus resembles Ennya Stål, particularly in the form of pronotum. The venation of tegmina, on the other hand, is very distinctive; the third apical cell is relatively large, occupying exactly the apical portion of the tegmina, almost circular and as large as the second one; it has apparently four apical cells because the vein $\mathbf{M}_{\mathbf{3}+4}$ joins $\mathbf{M}_{\mathbf{1}+\mathbf{2}}$ before reaching the marginal vein, looking to be one more discoidal cell.

\section{Metheisa lucillodes Fowler, 1896}

Figs 3-4

Metheisa lucillodes Fowler, 1896: 132; Metcalf \& Wade, 1965: 1021; Broomfield, 1971: 359 (lectotype desig.).

The lectotype is a female. The male is similar (fig. 4), just smaller, darker and with a shorter anterior process.

\section{Maturnaria Metcalf, 1952}

Maturna Stål, 1867: 555 (type species: Oxygonia ephippigera Fairmaire, 1846, by original desig.), (preoc.)

Maturnaria Metcalf, 1952: 230 (nom. n.); Metcalf \& Wade, 1965: 1054; Deitz, 1975: 103.

Stål (1867: 555) gives the following characterization:

"30(17). Corio a basi venas tres emittente, venis omnibus vel duabus vel basin versus contiguis vel, uti videtur, in unam interdum conjunctis.

31(52). Areola apicali alarum stylata, areolis adjacentibus ante illam sese tangentibus, stylo illius separatis.

40(33). Thorace rugis pluribus laevigatis, longitudinalibus, instructo.

42(41). Corio areola discoidali unica, pone medium corii et pone aream basalem secundam posita, instructo; areis basalibus tribus exterioribus dense punctatis, coriaceis, opacis; area apicali interiore angustiuscula; thorace leviter vel modice elevato.

43(44). Thorace dorso distincte compresso, ante medium sinuato, ante et pone sinum obtuse rotundato-elevato, angulis lateralibus haud productis, obtusis; ceteris ut in Oxygonia. - Maturna Stål. Typus generis: Oxygonia ephippigera Fairm.)"

Diagnosis. Pronotum navicular, low, with 3-4 lateral longitudinal carinae; metopidium convex, dorsum along median carina more or less foliaceous; apex not 
attaining the tips of tegmina. Tegmina with five apical cells, the third smaller; one discoidal cell $(\mathbf{R} 2+\mathbf{3})$.

Description. Head triangular, roughly punctured, almost as wide as long; superior margin arched, slightly sinuate; supra-antennal ledges with margins almost straight, in a continuous line with that of clypeus; this diamond-shaped, little wider than long, with a median longitudinal crest, tip rounded. Eyes ovate, normal. Ocelli slightly nearer to the eyes and superior margin than to each other. Pronotum navicular, low and convex anteriorly, covering about $1 / 3$ of tegmina, compressed after humeral angles and then slightly tumid; median carina percurrent and foliaceous; 3-4 lateral longitudinal carinae, commencing weakly at metopidium and, two of them, well marked posteriorly and reaching apex; dorsal contour line sinuous; humeral angles obtuse, not projected; post-ocular lobule normal, sub-quadrangular, the distance eye-mesepisternal hook about $1 / 2$ the width of eye. Tegmina with basal half exposed, coriaceous, and punctate as pronotum; veins $\mathbf{R}, \mathbf{M}$ and $\mathbf{C u}$ separated from base to midle, only joining at the junction with claval suture; with five apical cells and one discoidal $(\mathbf{R} 2+3)$. Wings with four apical cells, the second one peciolated.

Comments. This genus is very close to Metheisa Fowler differing in the absence of anterior process and in the venation of tegmina, with five apical cells.

\section{Maturnaria ephippigera (Fairmaire, 1846)}

Fig. 5

Oxygonia ephippigera Fairmaire, 1846: 311 (type loc.: Colombia)

Thelia varia Walker, 1851: 555 (type loc.: Colombia); Metcalf \& Wade, 1965: 1055; Broomfield, 1971: 383 (lectotype desig.).

Publilia tumulata Buckton, 1903: Pl. 39, figs 7-7a. (type loc.: Colombia); Broomfield, 1971: 381 (lectotype desig.), syn.n.

Metheisa fowleri Funkhouser, 1927: 321, syn.n.

Ecuatoriana fowleri; Metcalf \& Wade, 1965: 1018

Tynelia tumulata; Metcalf \& Wade, 1965: 886

Maturnaria ephippigera; Metcalf \& Wade, 1965: 1055

\section{Creonus, gen.n.}

Type species: Maturna lloydi Funkhouser, 1914

Diagnosis. Pronotum navicular, metopidium convex, dorsum low, slightly elevated after humeral angles; posterior process extending to tips of tegmina, with 3-5 lateral longitudinal carinae; post-ocular lobule more or less quadrangular, almost as long as the width of eyes.

Description. Head sub-triangular, roughly punctured, slightly more than twice wider than long; superior margin sinuate; supra-antennal ledges with margins arched, in a continuous line with that of clypeus; this triangular, twice wider than long, in same plan of vertex. Eyes ovate, relatively small. Ocelli equidistant from each other and to the eyes, and nearer to superior margin. Pronotum navicular, 
roughly punctured, covering more than half of tegmina and extending posteriorly as far as their apexes; with 3-5 lateral longitudinal carinae commencing weakly near metopidium and well marked after humeral angles, terminating all together at the apex; humeral angles blunt, not projected; post-ocular lobule sub-quadrangular, with the distance eye-mesepisternal hook almost equal to the width of eyes. Tegmina with basal half exposed, coriaceous, roughly punctured as the pronotum; veins $\mathbf{R}$, $\mathbf{M}$ and $\mathbf{C u}$ separated from base to middle, only united at the junction with claval suture; with five apical cells, the fifth larger than the fourth; one small discoidal cell $\left(\mathbf{R}_{\mathbf{2}+3}\right)$ present. Wings with four apical cells.

Comments. This genus is very close to Ennya Stål but without anterior process or projected humeral angles. The pronotum is low, slightly elevated behind middle. The post-ocular lobule is well developed, sub-quadrangular, with the distance eye-mesepisternal hook almost equal to the width of eyes. The venation of tegmina is similar to that of Ennya; the discoidal cell $\left(\mathbf{R}_{\mathbf{2}+\mathbf{3}}\right)$ is present; the wings are also similar, with four apical cells, the second one peciolated.

The name of the genus is in honor to Antonio José Creão Duarte.

\section{Creonus lloydi (Funkhouser, 1914), comb.n.}

Fig. 6-7

Maturna lloydi Funkhouser, 1914: 280 (Type loc.: Colombia, Caqueta)

Maturnaria lloydi; Metcalf \& Wade, 1965: 1055

\section{Aphetea Fowler, 1895}

Aphetea Fowler, 1895: 94 (type species: Aphetea inconspicua Fowler, 1895, by monotypy), (Fig. 9); Metcalf \& Wade, 1965: 1139; Deitz, 1975: 103.

Diagnosis. Pronotum navicular, low, without lateral carinae; tegmina with $\mathbf{R}$ and $\mathbf{M}$ united near base for a short distance; without discoidal cell.

Description. Head triangular, convex, almost three times wider than long, roughly punctured; superior margin sinuate; supra-antennal ledges with margins slightly sinuous, in a continuous line with that of clypeus; this triangular, abruptly deflected in frontal view. Eyes ovate, normal. Ocelli inconspicuous, slightly nearer to eyes and to superior margin than to each other. Pronotum navicular, low, roughly punctured, without lateral carinae, covering about half of tegmina, extending posteriorly as far as to their apexes; median carina percurrent; dorsal contour line somewhat sinuate above humeral angles, and near posterior third, sloping gradually to apex; humeral angles obtuse, not projected; post-ocular lobule triangular, well detached from the body, the distance eye-mesepisternal hook about twice the length of the hook. Tegmina with exposed basal half coriaceous and punctured as pronotum; veins $\mathbf{R}$ and $\mathbf{M}$ united along a short distance near base; five apical cells, the fifth the largest; without discoidal cell. Wings with three apical cells, $\mathbf{R}_{\mathbf{4}+5}+\mathbf{M}_{\mathbf{1 + 2}}$ forming one unique vein.

Comments. This genus forms, with Dioclophara Kirkaldy and Phormophora Stål, a group that presents only three apical cells in the wings. This reduction is 
due to the non ramification of $\mathrm{R}$, consequently, the absence of the peciolated cell. Aphetea Fowler has also the post-ocular lobule well detached from the body, forming an ear-like process. In some species the clypeus of male is tumid apically.

\section{Aphetea parvula (Fabricius, 1803), comb.n.}

Fig. 10

Darnis parvula Fabricius, 1803: 32 (type loc.: America meridionali)

Maturnaria parvula; Metcalf \& Wade, 1965: 1056.

Aphetea affinis Haviland, 1925: 252 (type loc.: Guiana, Kartabo); Metcalf \& Wade, 1965: 1140;

Broomfield, 1971: 329 (lectotype desig.), syn.n.

\section{Aphetea robustula, sp.n.}

Fig. 8

Diagnosis. Body robust; yellowish-brown with apical third darker.

Measurements (in mm), female/male. Total length 4.00/3.64; width of head 2.00/1.80; width between humeral angles 2.45/2.24.

Description. Holotype female. General color yellowish-brown; apical third of pronotum, basal portion of tegmina and undersurface of thorax, dark brown. Head triangular, roughly punctured; eyes normal; ocelli situated on an imaginary line that passes through center of eyes, slightly nearer to the eyes and superior margin than to each other; superior margin sinuate; supra-antennal ledges with margins sinuate; clypeus more or less pentagonal, with apical half deflected, somewhat flatened. Pronotum convex, posterior half more or less tectiform, extending to apexes of tegmina, covering about $2 / 3$ of them; roughly and densely punctured; median carina percurrent, the dorsal contour line slightly bisinuate, the first sinus just behind humeral angles and the second, deeper, at the middle, then descending in a wide arch to apex; humeral angles obtuse, not projected; post-ocular lobules triangular, projected backward and laterally. Tegmina about $1 / 3$ exposed, the basal half coriaceous; veins $\mathbf{R}$ and $\mathbf{M}$ united near base (the venation in this coriaceous part is not clear); five apical cells; no discoidal cell. Wings with three apical cells.

Male. Similar in form, just smaller; the coloration is darker and variegated.

Material examined. Holotype female labeled "Santa Cruz de la/ Sierra. Bolivia/ 26-IX-1953/ M. Alvarenga" Paratypes: 1 female and 1 male with same label data. The types are deposited in the collection Pe. J.S. Moure, Departamento de Zoologia, Universidade Federal do Paraná.

Comments. This species is very close to A parvula but more robust, somewhat short and sub-globular. The name of the species is allusive to the relatively robust body. 


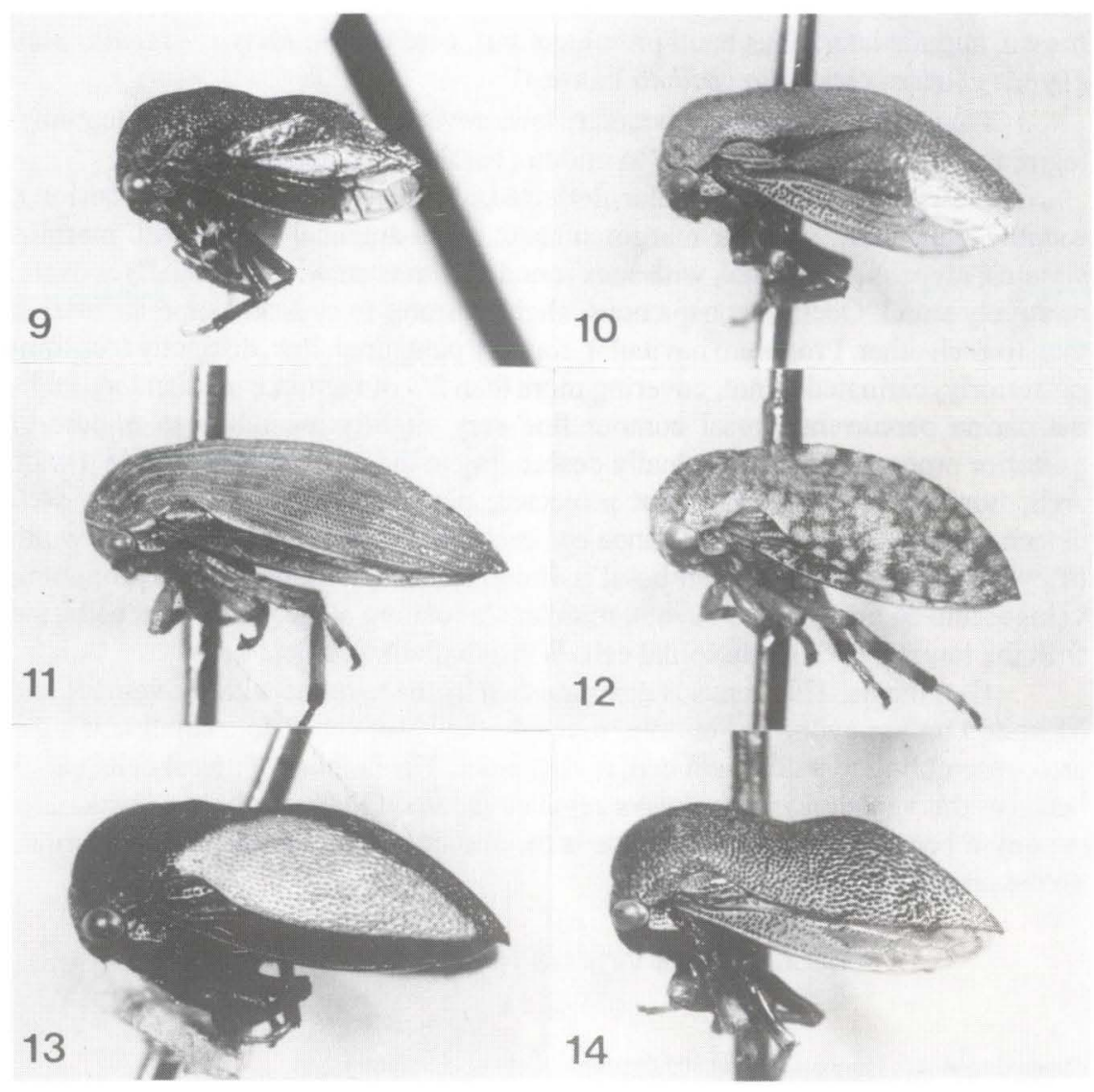

Figs 9-14. (9) Aphetea inconspicua Fowler, 1895; (10) Aphetea parvula (Fabricius, 1803); (11) Dioclophara viridula (Fairmaire, 1846); (12) Dioclophara variegata (Goding, 1926); (13) Phormophora maura (Fabricius, 1803), female; (14) Phormophora maura, male.

\section{Dioclophara Kirkaldy, 1904}

Lucilla Stål, 1867: 555 (Type species: Oxygonia viridula Fairmaire, 1846, by original desig.) (preoc.) Dioclophara Kirkaldy, 1904: 279 (nom.n.); Metcalf \& Wade, 1965: 1037; Deitz, 1975: 103.

Incolea Goding, 1926: 280 (type species: Incolea variegata Goding, 1926); Metcalf \& Wade, 1965: 1098; Deitz, 1975: 103, syn.n.

Stål (1867:555) gives the following characterization:

"45(32). Corio areola discoidali destituto.

49(46). Thorace anterius convexo et leviter elevato, pone angulos laterales altiore, ibidem saepissime subito compresso-elevato.

$50(51)$. Thorace parum alto, pone angulos laterales vix elevato, haud com- 
presso, angulis lateralibus haud prominentibus; ceteris ut in Ennya. - Lucilla Stål. (Typus generis: Oxygonia viridula Fairm.)"

Diagnosis. Pronotum navicular, low, covering more than $2 / 3$ of tegmina; tegmina with $\mathbf{R}$ and $\mathbf{M}$ united up to middle; basal cell $\mathbf{R}$ very small.

Description. Head triangular, deflected, less than three times wider than long, roughly punctured; superior margin sinuate; supra-antennal ledges with margins sinuous; clypeus pentagonal, with apex rounded, almost as wide as long. Eyes ovate, relatively small. Ocelli inconspicuous, slightly nearer to eyes and superior margin than to each other. Pronotum navicular, roughly punctured, low, distinctly tectiform posteriorly, carinated or not, covering more than $2 / 3$ of tegmina; median longitudinal carina percurrent, dorsal contour line very slightly ascending to middle of posterior process and then gradually descending to the apex, more or less in a wide arch; humeral angles obtuse, not projected; post-ocular lobule triangular, well detached from the body, the distance eye-mesepisternal hook about half the width of eye. Tegmina with exposed basal half coriaceous and punctured as pronotum; veins $\mathbf{R}$ and $\mathbf{M}$ united up to beyond middle; $\mathrm{Cu}$ running alone; five apical cells, the fifth the largest; without discoidal cell. Wings with three apical cells.

Comments. This genus is distinguished by the tegmina with the veins $\mathbf{R}$ and $\mathbf{M}$ united up to beyond the middle, reducing the basal cell $\mathbf{R}$ to a small lenticular area, resembling to a discoidal cell, at first sight. The number of apical cells varies because the venation is not always regular. Incolea Goding is here considered a synonym because the only difference is the absence of lateral longitudinal carinae on the pronotum.

\section{Dioclophara viridula (Fairmaire, 1846)}

Fig. 11

Oxygonia viridula Fairmaire, 1846: 305 (type loc.: Colombia, Bogota)

Dioclophara viridula; Metcalf \& Wade, 1965: 1038

Maturna multilineata Fonseca, 1942: 135 (type loc.: Brazil, Pará, Belém), syn.n.

Maturnaria multilineata; Metcalf \& Wade, 1965: 1056

This species presents the pronotum ornated with 6-7 lateral longitudinal carinae. The basal margin of metopidium is slightly expanded forward under of which the superior margin of head adjusts.

\section{Dioclophara variegata (Goding, 1926), comb.n.}

Fig. 12

Incolea variegata Goding, 1926:280 (type loc.: Ecuador, Tena, Napo River); Metcalf \& Wade, 1965: 1098.

Incolea viridis Goding, 1926: 280 (type loc.: Ecuador, Tena, Napo River); Metcalf \& Wade, 1965: 1099, syn.n.

This species differs from $D$. viridula by having the pronotum without lateral carinae; the posterior part is more elevated and tectiform. The coloration varies within the population, so $I$. viridis Goding is nothing but a variation, presenting a more uniform color. 


\section{Phormophora Stål, 1869}

Phormophora Stål, 1869: 28 (type species: Darnis maura Fabricius, 1803, by monotypy); Metcalf \& Wade, 1965: 1138; Deitz, 1975: 103.

Diagnosis. Pronotum with anterior half convex, constricted at middle and posteriorly more or less tectiform. Tegmina about half covered, with veins $\mathbf{R}$ and $\mathbf{M}$ united near base; basal cell $\mathbf{R}$ normal.

Description. Head triangular, apex deflected, almost three times wider than long, roughly punctured; superior margin very slightly sinuous; supra-antennal ledges with margins sinuous; clypeus rounded at apex, not inflated, as wide as long. Eyes ovate, normal. Ocelli inconspicuous, slightly nearer to eyes and superior margin than to each other. Pronotum convex from metopidium to middle of dorsum, then constricted and posteriorly distinctly tectiform, covering more than half of tegmina; dorsal contour line sinuate, slightly more elevated above abdomen and descending gradually to apex; humeral angles obtuse, not projected; post-ocular lobule triangular, well detached from the body, the distance eye-mesepisternal hook less than half the width of eye. Tegmina with exposed basal half coriaceous, punctured as pronotum; veins $\mathbf{R}$ and $\mathbf{M}$ united at base; $\mathbf{C u}$ running alone; five apical cells, the fifth the largest; without discoidal cell. Wings with three apical cells.

Comments. This genus is close to Dioclophara Kirkaldy in the form of pronotum, differing only by the more evident mid-dorsal depression. The venation of tegmina is similar to that of Hemiptycha Germar with $\mathbf{R}$ and $\mathbf{M}$ united up to near middle, leaving the basal cell $\mathbf{R}$ relatively large or about normal. The venation is not regular, presenting extra crossveins, sometimes joining $\mathbf{R}$ with $\mathbf{M}$ or $\mathbf{M}$ with $\mathrm{Cu}$.

\section{Phormophora maura (Fabricius, 1803)}

Fig. 13, 14

Darnis maura Fabricius, 1803: 30 (type loc.: America meridionali).

Phormophora maura; Metcalf \& Wade, 1965: 1039

Darnis dorsata Fabricius, 1803: 31 (type loc.: America meridionali), syn.n.

Phormophora dorsata; Metcalf \& Wade, 1965: 1038

This species presents sexual dimorphism. The female (Fig. 13) is more robust and frequently with a large yellow macula on each side of pronotum. The male (Fig. 14), on the other hand, is entirely greyish-brown. Fabricius gave different names for these two forms.

\section{REFERENCES}

BRoomfield, P.S. 1971. A Catalogue of the membracid types (Homoptera: Membracidae) in the British Museum (Natural History). Bull. British Museum (Natural History), Entomology 25 (8): 327-386.

BuCKTON, G.B. 1903. A Monograph of the Membracidae. London, L. Reeve \& Co. Lmtd., 296p. 
CoQueBerT, A.J. 1801. Illustratio Iconographica Insectorum quae in Musaeis parisinis obsevavit et in lucem edidit Joh. Christ. FABRICIUS, praemissis edjusdem descriptionibus; accedunt species plurimae, vel minus aut nondum cognitae. Paris. 44p.

DeITZ, L.L. 1975. Classification of the higher categories of the New World treehoppers (Homoptera:Membracidae). North Carolina Agr. Exp. Sta. Tech. Bull.225: 1-177.

FABRICIUS, J.C. 1803. Rhyngota. Systema Rhyngotorum secundum ordines, genera, species, adiectis synonymis, locis, observationibus, descriptionibus. $314 \mathrm{p}$.

Fairmaire, L.M.H. 1846. Revue de la tribu des Membracides. Ann. Soc. Ent. France 4: 235-320.

FonSECA, J.P. DA. 1941. Contribuição para o conhecimento dos membracídeos neotrópicos (IV). Arq. Inst. Biológico 12: 129-140.

FOWLER, W.W. 1895. Order Rhynchota; Suborder Hemiptera-Homoptera. (cont.) Biol. Centr. Amer. 2: 89-112.

1896. Order Rhynchota; Suborder Hemiptera- Homoptera. (cont.) Biol. Centr. Amer. 2: 129-136.

FunKHOUSER, W.D. 1914. Report on a collection of Membracidae from the Colombian Andes, taken by Mr. John Thomas Lloyd. J. N.Y. Ent. Soc. 22: 275-281.

1927. General Catalogue of the Hemiptera. Fasc. 1. Membracidae.

North Carolina State College, Raleigh, 581p.

Germar, E.F.. 1833. Conspectus generum Cicadariarum. Rev. Entomol. Silbermann 1: 174-184.

GodING, F.W. 1926. New Membracidae, II. J. N.Y. Ent. Soc. 34: 279-281.

Haviland, M.D. 1925. The Membracidae of Kartabo, Bartica District, British Guiana. Zoologica 6 (3): 229-290.

KIRKALDY, G.W. 1904. Bibliographical and nomenclatorial notes on the Hemiptera. No. 2. The Entomologist 37: 279-283.

MetCalf, Z.P. 1952. New names in the Homoptera. J. Wash. Acad. Sci. 42: 226-231.

Metcalf, Z.P. \& V. Wade. 1965. General Catalogue of the Homoptera.

Membracoidea. Sec. 1-2. North Carolina State University, Raleigh, 1552p.

STÅL, C. 1867. Bidrag till Hemipterernas Systematik. Ofvers. Kongl. Vetensk. Forhand. 7: 491-560.

. 1869. Hemiptera Fabriciana. Svensk. Vetensk. Akad. Handl. 8: 18-58.

WALKER, F. 1851. List of the Specimens of Homopterous Insects in the Collection of the British Museum. London, British Museum, part 2, p.261-636.

Recebido em 14.V.1996; aceito em 11.X.1996. 